\title{
Climate Change Adaptation Planning, Measures and Multilevel Governance Approaches in Pakistan: Climate change and its risks on natural resources and human health of the
} country and Governments' responses

\author{
Shahzad Ismail ${ }^{1}$, Gulnaz Malik ${ }^{2}$ \\ ${ }^{1}$ Executive Director, New World Hope Organization (NWHO), Pakistan \\ ${ }^{2}$ Armed Forces Institute of Cardiology/National Institute of Heart Diseases, Rawalpindi, Pakistan
}

\begin{abstract}
Climate Change is a complex challenge that the world is facing. Pakistan would be the most affected by climate-related disasters because of a lack of proper institutional, financial, and technological mechanisms to control the risks of climate change (Yamin, et al.,2005). Past natural disasters show that the local governments with insufficient financial resources, planning, institutional, technical adaptation capabilities remain unable to overcome natural disasters.

Pakistan is an agricultural country, and its economy relies on the agriculture field. However, the growth rate of agriculture is decreasing because of environmental changes that are having great harmful effects on the already limited water resources(The World Bank Group, 2016; Khan, et al., 2016). Long-term climate change and frequent extreme climate events have significant negative impacts on people's health that can cause death, disability, or suffering worldwide, especially in developing countries.

This paper will recommend climate change adaptation and measures to reduce environmental degradation that will help create practical results for disaster reduction, public health, and water and natural resources' improvement of Pakistan.
\end{abstract}

Keywords- Climate Change Adaptation, Disaster Reduction, Human Health, Natural Resources Improvement Polices.

\section{INTRODUCTION}

In the twenty-first century, climate change is a severe risk for the economy, resources, and security of the world. Its adverse effects are being felt all over the globe. Climate-related disasters have affected millions of people on our planet. They are expected to affect millions of people, especially in developing countries, because their economy and social development heavily rely on climatesensitive natural resources. Along with this, developing countries have less skill to control the impacts of environmental degradation effects. (Yamin et al., 2005).

It is expected that adverse health impacts of weather and climate will be on people of all ages, especially the greatest on older people, children, subsistence agriculturalists, and indigenous or tribal people in low-income countries. People's health and healthcare management systems have now improved worldwide as compared to the past. However, healthcare improvement, population health, and care management arrangements are not the same in every country in the world. The average years of life have increased in some parts of the world over recent decades. However, life expectancy has already declined in many countries of the world, especially in developing countries during the last twenty years due to the spread of epidemic diseases such as HIV/AIDS, Ebola virus disease, and coronavirus. Extreme climate events can rise further the vulnerability of human health because climate-related extreme disasters force people to migrate to other unsafe places. As a result of forced displacement due 
to climate-related disasters, people lose the stability of their families, and they are more likely to be infected by epidemic diseases (IOM, 2009; IPCC-WGII, 2007).

Pakistan's climate is generally warm and lies in the world where the temperature is rising even faster than the global average, rainfall patterns are changing rapidly, and the sea level is rising due to ice melting. All these changes contribute to extreme events in the form of heat waves, earthquakes, tornadoes, flooding, and droughts(Rasul \& Ahmad, 2012). Pakistan is prone to a variety of climate-related disasters. These disasters have made history in Pakistan because of their harmful effects on the residents' health, on the natural resources, and the economic health of the country. The issue is that climaterelated natural disasters, whether they are extreme or small scale, will continue to occur. Most of the natural disasters happen suddenly again and again with little or no warning and have many side effects at the national and the local levels(Wei Choo, 2008).

Pakistan is mostly an arid and semi-arid country, with approximately $80 \%$ of its area falling in these categories. Since independence in 1947, many natural resources of Pakistan have been damaged, and a large portion is under significant risk every year due to the natural disasters, the lack of planning, awareness, and control before, during and after the disaster events (Iqbal, et al., 2014). The negative consequences of natural disasters are being seen in different locations with severe effects on the food production, human health, the infrastructure, the resources and the livelihoods of Pakistan (United Nations Environment Programme (UNEP), et at., 2013).

In general, when any climate-related natural disaster occurs, people look towards local governments and related agencies for immediate relief aid and transitional recovery assistance. Over the past decade, Pakistan has faced many natural disasters. Unfortunately, the past natural disasters show that the local and the central government departments and the related national agencies could not provide immediate relief and recovery to the affected people during an emergency(Mayo, et al., 2013). The core cause for the low performance of the concerned departments is that they have a lack of adequate response mechanisms and coordination platform among the line agencies, the lack of skills of the local officials and the lack of strategies for dealing with the natural disasters (Ainuddin, et al., 2013).

Local governments can better react to the risks of environmental changes. They can produce positive results in terms of reduction of local pollution, collection waste, natural resources management, and economic growth in a situation where local data and funding for adoption are available, and adaptive responsibilities are clear (National Climate Change Adaptation Research Facility, 2012). Pakistan is on the front line of the climate crisis and its adverse effects. There are a lot of obstacles to coping with environmental degradation. Still, the common obstacles within the local governments' context in the world can be a result of societal and organizational behavior, inconsistent governance structure, financial, economic and regulatory obstacles, and insufficient information, awareness, and knowledge of environmental problems (Jensen, et al.,2016). Adaptation and the adaptive capacity building to deal successfully with gradual changes to climate is not a one-time process. On the contrary, it is an ongoing practice of training, response, and correction(The World Bank Group, 2011). Building effective adaptation strategies to control environmental degradation that is operative from the local to the national government level will support the country's economy.

Devolution of powers from top to bottom and effective and decentralized strategies to control climaterelated national disasters can significantly reduce the loss of lives, the loss of infrastructure, and properties that happen due to environmental degradation (Mayo, et al., 2013). The climate change decision making and planning process is in the hands of politicians of a country. Climate change can only be tackled effectively if the policymakers increase the ability, involvement, resilience, and skill of the local public and involve both the local officials and local non-profit organizations in the climate change actions and policymaking process (Ainuddin et al., 2013).

In light of the empirical evidence, this paper will examine the environmental degradation awareness, its impacts, and the adaptation system and process in Pakistan. It will argue that climate change effective policies, planning, and activities at the local government levels can produce positive effects for disaster reduction, natural resources and human health improvement, environmental protection, and economic and community development in Pakistan. The paper will identify those challenges and provide analysis about the main obstacles to adaptation and what adaptation practices to control environmental degradation are planned to overcome climate change impacts. Further, the possible role of Geographical Information System (GIS) along with the idea of environmental awareness, will also be evaluated for improving awareness about environmental degradation. Finally, this paper will identify and recommend some specific strategies, realistic policies, and practical solutions 
for developing and strengthening the capability of the local governments.

\section{Objectives}

- To examine the Pakistan government's response to climatic change and impacts of climate-related events on Pakistan's natural resources, and people's health

- To evaluate the awareness level of environmental degradation and its effects among local government employees

- To review existing climate change policies and the adaptation systems, and planning and assess the adaptive capacity of key stakeholders

- To identify significant gaps in climate policy and planning and how it can be filled in a successful manner

\section{Research Questions}

- How Pakistan's serious problem of limited natural resources and low environmental awareness will change climate change consequences for the country?

- What are the main obstacles to adaptation, and which adaptation policies are already planned to reduce climate-related disasters at the local levels in Pakistan?

- Which adaptation system, policy, and practice would be the best in Pakistan in reducing climate change adaptation barriers?

- Will the decentralization of government disaster institutions be crucial to reducing the disaster impacts at all levels?

\section{STUDY METHODS}

Several methodologies will be used to gather information in writing this paper. These include literature studies and secondary sources, case studies and research papers, surveys, and evaluation reports of climate change challenges and adaptation areas. The paper is an examination and analysis of journal articles, dissertations, research analysis, and books from different sources. These documents and reports were obtained from the Ministry of Environment (MoE); the National Disaster Management Authority Pakistan (NDMA); the Ministry of Climate Change(MCC): the Ministry of Finance; the Provincial Disaster Management Authority (PDMA); the Indus River System Authority; the Pakistan Flood Commission; and the Pakistan Agriculture Research Council, World Health Organization (WHO) and Pakistan Planning Commission. Besides these sources, the paper will use information from the reports, documents, and policy briefs obtained from different semi-governmental and non-governmental organizations working in and for Pakistan.

Also, the paper will use the developmental working knowledge gained at the national and international levels in the project management, public healthcare, and emergency preparedness field. Furthermore, The learning experience from international professional training courses and conferences on the subject of environmental management, disaster relief, and public healthcare is also an asset that has been very helpful in identifying major obstacles to the adaptation of climate and natural resources management policies and strategies. Based on a literature study and our working experience, the paper will recommend various possible practical solutions for the Pakistan government that would strengthen the local governments and empower the communities to combat environmental change.

\section{LITERATURE REVIEW}

The literature review section will provide an overview of climate change and its impacts on natural resources and public health, identify priority concerns, and focus on environmental change adaptation measures, mitigation, future challenges, and find the role of climate awareness and the local government in developing adaptation. Finally, based on the relevant literature, the paper will discuss the climate change response strategies of different countries and find the most vital sectors for environmental change adaptation.

\section{What is Climate Change}

Environmental change and degradation, which is a long time variation in the world's temperature or seasonal patterns, affects people, agriculture, sea levels, and ecosystems and increases the risk of natural disasters (UNEP, 2013). The climate is changing due to the use of fossil-fuel burning, the release of industrial waste, the burnings of agricultural wastes, the use of insecticides and pesticides, mining, and deforestation (Simeone, 2006). These human activities increase the level of greenhouse gasses (GHG) / carbon dioxide (CO2)in the air and produce greenhouse effects. According to the United Nations Framework Convention on Climate Change (UNFCCC), human activities are believed to be changing the structure of the earth's atmosphere. Environmental change is happening primarily due to a rise in the amounts of aerosols (small particles), cloudiness, and greenhouse gasses such as carbon dioxide (CO2) (UNFCC, 1992). 


\section{Climate Change and Public Health}

Air pollution and global warming can significantly influence human health and increase disease mortality. Non-infectious diseases such as cancer, kidney disease, depression, and heart disease are multiplying in developing countries. Because environmental change has a strong relationship with public health that has caused and will create more enormous implications for human health. According to Baaghideh 2017, rising global temperatures and air pollution will increase the mortality rate of non-infectious diseases in future decades.

\section{Climate Change Adaptation plus Mitigation}

The common meaning of the word "adapt" is to make and become suitable for something or follow an idea, method, or course of action. According to the UNDP, the word adaptation means "all changes in a system, compared to a reference case that reduces the adverse effects of climate change" (United Nations Development Programme, 2003). The IPCC says that "adaptation is a modification in environmental, societal, or financial structures in response to sincere or anticipated climatic variation and their reactions or impacts" (IPCC, 2016). All the definitions give the idea of regulation, climate variability, and extreme natural disasters' reduction rule. All the above explanations of adaptation of natural resources and climate management express that it is a modification, improvement, and arrangement in institutions and in structures to mitigate the expected impacts of environmental change and climate-related disasters. Simply climate change adaptation means that taking an effective action to lessen the extreme effects of environmental-related disasters in the most effective way by taking benefits of opportunities that can occur anytime, for instance, developing an effective early warning system, using limited natural resources more efficiently, building higher and stronger river walls and dams to prevent floodwaters and switching to more droughttolerant crops, etc.

Mitigation refers to any strategy or act that has been taken to lower the severity of environmental change impacts in the long term. According to the UNEP, climate change mitigation is the action and strategy of using new or old technologies, equipment, or management practices that lessen the greenhouse gasses, which are released into the air (UNEP Climate Change Mitigation, 2016).

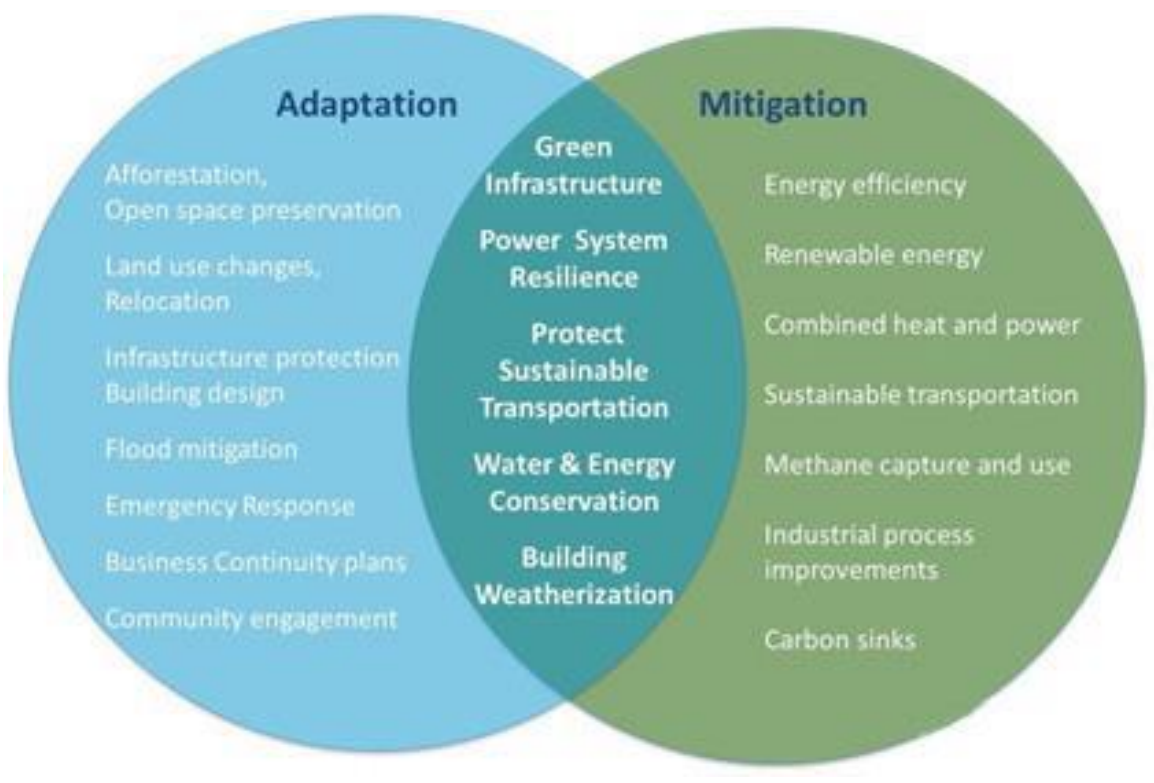

Fig. 1. Adaptation Plus Mitigation Synergies

Source: (The Center for Clean Air Policy, 2013)

Adaptation and mitigation strategies to climate degradation are both compulsories to decrease the dangerous outcomes of environmental change because adaptation in the field of environmental degradation refers to the capability of a system to mitigate the harmful outcomes of environmental change and enhance the resilience of disaster-prone country and people.

\section{Local Governments and Climate Change}

The Stern and International Energy Agency (IEA)'s report says that metropolises are known as the largest producers of GHGs emissions; they are responsible for up to $75 \%$ of the global emission of GHG. So, researchers of the cities' governance on climate degradation have grown up rapidly during the last ten 
years, and cities' responses to environmental change have grown all over the world. For more than a decade, at an international level, there have been many debates and discussions between nation-states to reduce the emission of GHGs. Still, it has been seen in an international relations practice that global environmental governance often takes place at the global level. However, many reports suggest that the nation-states will not be able to meet their international commitments for dealing with climate change without precise engagement with subnational and local governments' action plans. Carbon emission originates from the actions that are rooted in cities, so the local government is the most appropriate domestic authority to address the specific global environmental problem and for bringing a depletion in CO2 (M.Betsill \& Bulkeley, 2006).

The International Council for Local Environmental Initiatives (ICLEI), one of the leading institutions of local governments were formed first in the 1990s by the U.S and Toronto federal government and numerous private organizations to address the climate change and environmental issues of local governments internationally. In 1990, The second institution, "Climate Alliance," was established as a union between European metropolises and the public to protect the rainforest and reduce 50 percent GHG emissions by 2030 (Bulkeley, 2010). The Cities for Climate Protection was third initiated with the support of the European Union (EU)in 1993 by the local governments of the UK, France, and Germany. This initiative was taken to give the authority to local governments to protect the climate and the environment at local levels through measurement, obligation, planning, executing, and monitoring(UN HABITAT \& ICLEI, 2004). Through these international networks, the substantial responsibility of the local government in environmental change governance is acknowledged as crucial to the advancement of a country. Currently, the agreement of international networks maintains the local governments' importance and recognizes that local governments convey the local needs more clearly and quickly than the national levels of government. According to the) and these three transnational municipal networks, a local government has a great experience dealing with environmental issues and more realistic compared to higher government levels, and local government has the authority to overcome any circumstances in a more sustainable way. The local governments of many countries are joining these networks, and the members of these networks are increasing every year. But despite the international policy interventions at the local government level since 1990, there is an enormous gap so far in the implementation of actual actions to reduce GHG emissions. Consequently, one significant benefit has achieved during the last several years that the debate on international climate policy has been shifted to the agenda of local politics (M.Betsill \& Bulkeley, 2006).

\section{Challenges to Climate Change Adaptation}

The scale and severity of natural hazards, for instance, severe thunderstorms, floods, earthquakes, glacial melting, and droughts, pose severe threats to all sectors of society. They have grave impacts on the development, health sector, and ecosystems of a country. Although climate change is a severe problem, governments usually give less importance to it than other national issues (Lorenzoni \& Pidgeon, 2006).

Lorenzoni and Pidgeon (2006) and Neuhoff (2015) indicate in their books that nowadays, policy indicators have gained an increasing level of attention in developed and developing countries. There can be many obstacles that can hinder the implementation of policies. These books offer some significant suggestions, or obstacles as barriers to climate adaptation, which are:

Effective Adaptation...

(1) needs coordination, awareness, and training

(2) wants more capital

(3) needs professional skill

(4) needs to add with regulatory requirements

(5) is a complicated process and others will take benefits

\section{Climate Change Adaptation Measures}

Both policies and measures are required for climate adaptation in different ways. Policy refers to decisions, instruments, and plans with the means of implementation to change economic structures and individual behaviors. For instance, a water supply policy of a county may include many instruments and policies, which may include dam construction plans, rainwater harvesting, and artificial wetlands plans, etc. In contrast, measures refer to a course of action that is taken to achieve a specific purpose. In a climate change adaptation context, measures are actions that prepare a country for the consequences of environmental change and work according to the chosen policy. Environmental change adaptation measures contribute to the national goal. They are designed for both current and future consequences of environmental change, such as the implementation of water supply and public health programs, extreme events prevention projects (OECD, 2006; Burton et al., 2005). 
The following options are essential adaptation measures to prevent, reduce, and mitigate short to long-term effects of environmental change.

\section{- Adaptation Measures}

- Policy Measures

- Economic Measures

- Technological and information systems Measures

- Capacity building for staffs

- $\quad$ Monitoring and Predicting

- $\quad$ Risk Sharing and

- Awareness Raising

Climate change adaptation measures are usually specific actions that prepare a county and communities to decrease vulnerability to the consequences of environmental variation(San Diego Forward, 2014).

\section{Environmental Literacy}

Folks' environmental awareness and education are vital, which is the most potent tool for climate change awareness and prevention. The primary purpose of climate awareness is a behavioral change of people so they can act in a more environmentally friendly way (UNEP, 2007). Environmental knowledge and education play an enormous part in raising awareness of environmental challenges and shaping the attitudes and behaviors that can protect the environment, human health, and natural resources of a country and contribute to the sustainable development of a country (The British Council, 2013). A lack of education and awareness on environmental issues make a country more grievous to the dangerous effects of environmental change. Generally, people do not have much environmental awareness, and they do not know how to conserve the climate and use natural resources in an environmentally sound manner (Srivastava, 2016).

Dissemination of environmental knowledge, skills for mitigation and adaptation at a country level are crucial for environmental protection and improvement of the health of the environment and people. It must be an essential part of the education system at the national level. Environmental training and awareness give not only knowledge to people about environmental change, but also, it develops thinking, and implementation skills of environmental protection and this necessary expertise can be conveyed at the grass-root level by including in the curriculum of schools. According to United Nations Educational, Scientific, and Cultural Organization, there are two main strategies for the development of environmental change awareness and skills on a country level among citizens and professionals that contribute to the solution of the environmental problems(Srivastava, 2016; UNESCO, 1992).

1) By creating climate change awareness of the public through the education system.

2) By providing environmental education and practical training through professional groups.

\section{Why Local Government?}

Local government is an administrative body at the local level that delivers services and goods for small geographic areas. It is divided into three major types: rural government, urban government, and the provincial government (UNDP et al., 2010). Local government is an ideal place to manage environmental change and its devastating effects on natural resources and folks, but in many countries, adapting to environmental change is a new topic, so no detailed reports and researchers are generally available at local government level regarding climate change adaptation and measures. There is no one easy, short, or magic formula to tackle climate change. Some countries are focusing on actions to reduce GHGs at city levels, and some are working to mitigate anticipated adverse environmental impacts at the local levels(National Research Council, 2011). These countries are trying to manage the negative impacts of the environment and reducing the magnitude of global warming. Most of the climate change discussion on the discipline of environmental variation and its strategic implications have been shifted at an international level rather than the local or national level. As a result, local governments and officials are not well familiar with the knowledge of the environment and environmental degradation and its strategic implications. They do not contribute effectively to climate change mitigation (UNDP et al., 2010).

Local government can play important roles to increase community adaptation capacities and to take leadership responsibility and actions in setting the environmental change policies, standards for environmental protection, for the protection of human health and pollution control. Because the local governments directly include all local public-sector development programs and they have good knowledge of the delivery of government services, and local government officials are the first responders when climate-related disasters occur(Morrill, 2016). Therefore, local governments can achieve a higher success rate in achieving the objectives of environmental, natural resources, and 
human health protection (The U.S. Department of State publishes eJournal USA, 2011).

\section{Conclusion}

The study has revealed through the literature review that variability of the environment has many implications from the household to the national and international level because it is not just an environmental matter. Climate impacts will be most significant and will have huge impacts on every sector of the global economy. Effective adaptation of natural resources and environmental management, climate change literacy, and awareness, environmental change mitigation, and actions are vital to mitigate the likely destructive effects of climate degradation on people's health, natural resources, and the environment. Long-term changes in the environment will create more extreme weather disasters that will put severe pressure on people, the local governments and its institutions, natural resources, and the environment. It will be necessary to find the best practices, policies, and tactics to tackle environmental change and its negative impacts.

\section{Discussion}

The discussion section will include information about the harmful effects of environmental change in Pakistan, strategies to address it, and the deficiencies in those strategies.

\section{The Country Status}

Pakistan is highly vulnerable to extreme weather disasters due to its topographical position, high population density, weak institutions' planning, and the economic condition of the country. According to the German Watch Report 2013, Pakistan was ranked as 8th in the countries that were most affected by climate change events (Germanwatch, 2013). Most parts of the country's land are dry, parched, and barren, with very few forests due to the variabilities of natural atmospheric processes. Thus, droughts occur mostly in southern parts of the country, which kill animals and crops and leave people with a low supply of food. The natural environment of the country is severe, and the arid parts have fluctuating temperatures, e.g., in the cold season, it decreases, and in the hot season, it rises. The northern parts of Pakistan are considered dry areas and have little rainfall because, in these areas' monsoon rains do not occur.

\section{Environmental Effects in Pakistan and Local Governments}

Climate change and its impacts will not only affect the economic growth, the natural resources, and the people's health of Pakistan, but also it will obstruct the accomplishment of the Sustainable Development Goals (SDGs). The effects of extreme climate hazards on the people and the development of Pakistan can be assessed by the fact that climate-related disasters have killed about 6,209 people and affected nearly $1,8,521,926$ people in the period between 1995-2004. During the period from 2005 to 2014, climate-related disasters have killed about 82,802 people and affected approximately 49,784,339 people (IFRC, 2015).

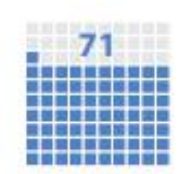

Flood
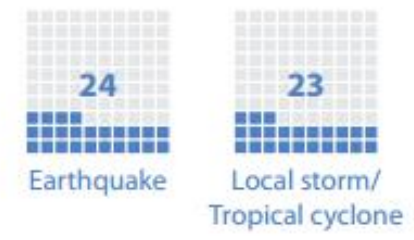

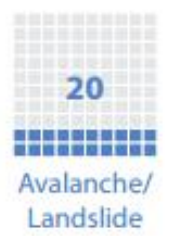

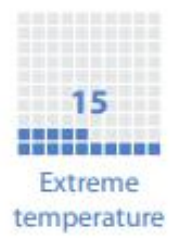
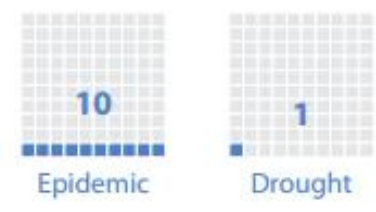

Fig. 2. Number of Climate Disaster Events in Pakistan Since 1900

\section{Source: (UN OCHA, 2011)}

Climate change and extreme weather events have already created many problems for Pakistan. Pakistan's provisional governments, including district governments, have been unsuccessful in tackling natural disasters effectively because the central government of Pakistan did not introduce a sound local government system to deal with natural disasters. The central government passed an act in 2013, in which relief efforts, disaster management activities and environment control schemes will be under the control of the local governments which will be responsible for disaster management, providing disaster relief efforts in the event of any disasters and the local governments will prepare and implement environment control schemes. Still, unfortunately, the central government has failed to institutionalize the district's level management authorities so far. The disaster or emergency dealing departments are working in an uncoordinated way to reduce the harmful effects of disasters; for example, the Rescue 1122 Service is one of the largest emergency services in Pakistan providing relief during an emergency, and disastrous situations. But this department is not working under the PDMA. Similarly, irrigation, 
agriculture, and health departments are performing their jobs at the provisional levels in an uncoordinated way. They are not performing their jobs according to the National Disaster Management Act, 2010, which was designed to deal with the disasters and the climate (Sharif, 2013).

\section{The Most Vulnerable Sectors to Environmental Change}

National Climate Change Policy (NCCP) 20142030, UNEP, 2000 and Piracha, et al., 2016 reports have identified the most climate-vulnerable sectors for Pakistan. These include the water, agriculture, and food sectors. Climate change has already harmfully affected the drinking and marine water resources. It will further affect water sectors, which will increase the possibilities of water contamination and create challenges to human health and lead to Water-related Illnesses. Water resources, including rivers, lakes, dams, and underground aquifers for Pakistan, are like tires of a vehicle. So, without tires or with puncture tires, a vehicle cannot run properly.

Similarly, a country with severe water scarcity becomes disabled in terms of development and economic growth. In Pakistan, water protection planning and awareness are minimal, creating a problem for the people, and water resources are under severe strain due to climate change and overpopulation.

A survey was conducted by Piracha, et al., 2016 in local union councils of Lahore, Pakistan, to ask the current and upcoming consequences of environmental degradation in Pakistan from the local officials. The opinion of the local officers shows in the study that environmental variation has already affected the water and food sectors and will continue to affect these resources.

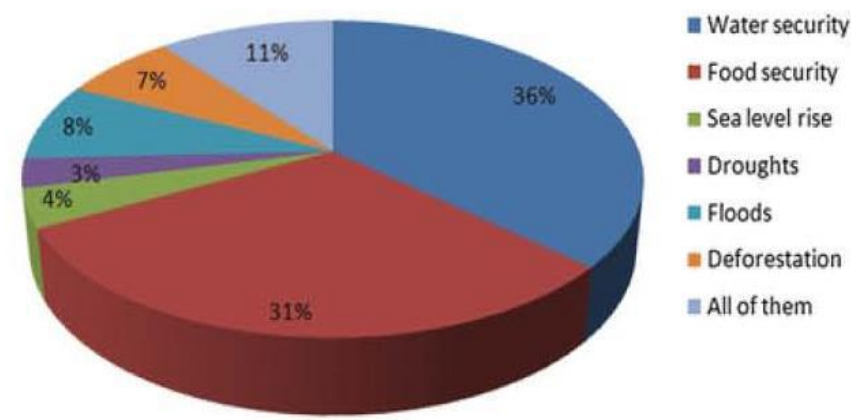

Fig. 3. Local Official's Opinion about the Most Unsafe Sectors to Climate Change.

Source: (Piracha, et al., 2016)

The water crisis will damagingly affect the agriculture sector. Agriculture is the core industry of Pakistan's economy that contributes 25 percent of Pakistan's Gross Domestic Product (GDP) and 60 percent of export earnings, and the industry provides employment opportunity to about 60 percent of the population. Furthermore, both population growth and climate change put pressure on the already insufficient and scarce water resources of the country. It is assessed that the need for water in Pakistan will increase five times from 2020 to 2050 because of population growth. The country has the most extensive canal-based irrigation system, but it is facing critical water shortages due to environmental degradation and poor planning and water management.

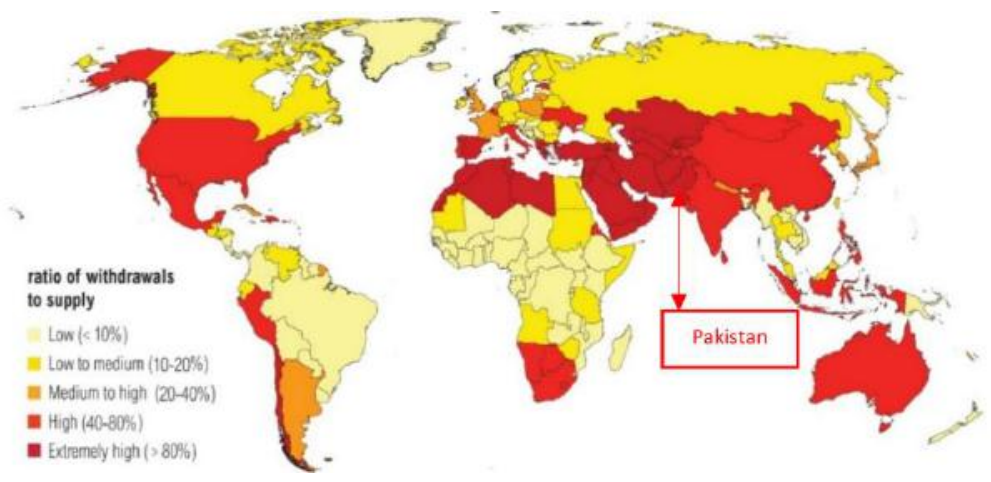

Fig. 4. Most Expected Water-Stressed States by 2040.

Source: (World Resources Institute, 2015)

In the above map, Pakistan is located in an area where many countries of the world will face extremely high-water stress by 2040. There are many studies available in Pakistan on the water crisis, water 
scarcity, adverse environmental effects on water resources, and crop yield. However, these studies do not provide details about adaptation strategies in the water sector. One study is available so far that was carried out by the UNEP that provides details about climate change adaptation efforts on Pakistan's water, and the adaptation measures need to be adopted in Pakistan. The study suggests that the water protection, management, and sustainability can be achieved in Pakistan by the construction of small dams, retention pond systems, water conservation measures in rural and urban areas, and through awareness of the people and the farmers regarding water supply issues(UNEP, 2000).

\section{Obstacles to Adaptation in Pakistani Local Governments}

The past climate change-related disasters indicate that the government line agencies and the local governments with limited financial resources and lack of technical skills remain unable to control catastrophic natural disasters. Lack of awareness, coordination, and training has always been the main reasons for the low performance of the local government's departments and government line agencies. The Pakistani constitution says that the local governments of Pakistan are a provincial subject (Mayo et al., 2013). They will work under the provincial governments; thus, all Pakistan's four provincial governments will give instructions to their respective local government's legislation (Sansom et al., 2013, p.47). The National Disaster Management Act, 2010 of Pakistan, has categorized three stages of intervention: (1) unions, (2) tehsils, and (3) districts level governments. But unfortunately, the provincial governments have all been unsuccessful in introducingng a genuine and effective local government system so far that have the ability to control extreme environmental degradation and manage frequent disasters at the local levels(Mayo et al., 2013).

Based on the study of three research papers of Janjua (2011), Mayo (2013)and Shahid (2015) which were conducted in Pakistan on the subject of an adaptation strategy and local government, these studies have found and identified that there are three significant obstacles to environmental change adaptation at the local levels in Pakistan.

These obstacles are:

1. The lack of data and adequate awareness

2. The lack of sufficient/effective methods, policies or tools at the local government level

3. The lack of adequate funds

Pakistan and International Protocols on Climate Change

ISSN: $2456-1878$
Pakistan is a vast and diverse state with a range of seasons, socio-economics, agricultural patterns, topography, and variable conditions of weather. The country is trying to establish a balance between the economy, people's development, and climate protection. In this regard, as an official unit to many international agreements and conventions, Pakistan has been vigorously involved in the environmental protection meetings and the global climate conferences from its creation in 1947. At the international level, Pakistan has signed and ratified fifteen Multilateral Environmental Agreements (MEAs), conventions, and protocols (MCC,2016). The international commitments of climate help to provide steps to fight against environmental degradation at the country level. Thus, the NCCP is trying to put international environmental change adaptation actions in its national policy frameworks. However, many adaptation strategies at the national level have been unsuccessful that don't include both negative and positive sides of climate change. For instance, the emergency and disaster risk management strategies of Pakistan don't recognize the climate change perspective. It does not cooperate practically with the likeminded local government departments to decrease the vulnerability to environmental change(Khan et al., 2016). Furthermore, the financial resources and capacity to tackle environmental change and its consequences at the local level are not considered in the National Environment Policy (NEP) and NCCP. Nor is there any research available publicly in terms of the local government involvement concerning environmental change adaptation and implementation of the policies.

\section{Environmental Knowledge in Pakistan}

Environmental awareness and public education in Pakistan can lead to better environmental planning and management (Awais \& Zareen, 2016). According to UNESCO, 2012, educational attainment, from necessary to a higher level, is very low in Pakistan. The country ranks in the second position, where about five million children were out of school in 2012 only. Furthermore, Pakistan has almost 49.5 million illiterate adults, and this is the third-highest position globally. The high rate of literacy in a society can reduce the process of environmental management. According to Howe, 2009, literate persons are more concerned about environmental matters (Howe, 2009).

A detailed survey was carried out in the 150 local union councils of Lahore, Pakistan, both in the urban and rural areas by Awais \& Zareen, 2016 to find out the awareness level about environmental degradation among the local government officers. The findings of the study show that 53 percent of the local government officers of 
the countryside councils were not aware of the phenomena of environmental degradation, and only 47 percent of local officers of urban union councils had some knowledge of environmental degradation.

\section{GIS's Role and Environment}

GIS can be used professionally for developing climate change maps, increasing climate change awareness, and addressing climate-related disaster management processes(ESRI, 2014). Maps and visual displays are a better way of communicating information between the local inhabitants and different public agencies. In this way, they can better understand a complicated climate situation. The latest studies of Awais Piracha (2016) and Zareen Shahid (2012) show that the local government officials in Pakistan do not have the knowledge of GIS and they do not know its importance in climate change planning, managing and mitigating natural disasters (Piracha, et al., 2016; Zareen, 2012). Lack of environmental awareness and lack of knowledge among local people and local government officials can impede climate adaptation in Pakistan.

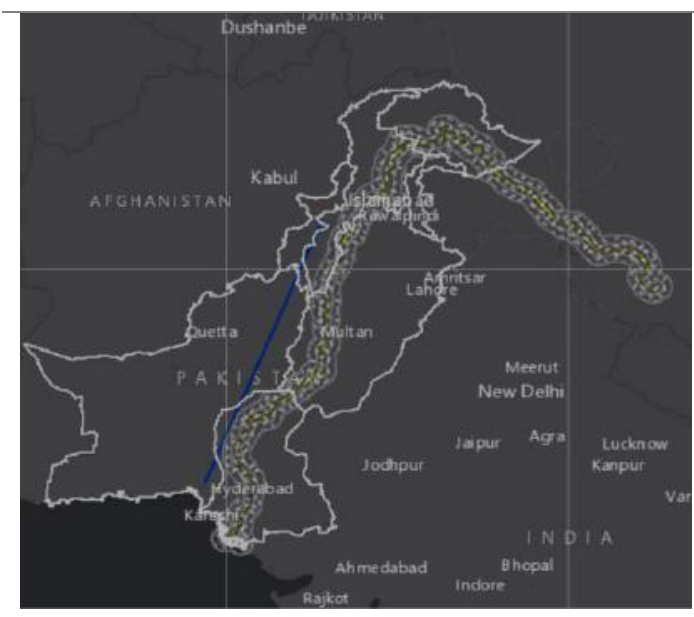

The excessive input of water in the Indus River in Pakistan during Pakistan Floods 2010-2011
Floods are very common and cause huge damages to infrastructures, crops, agriculture lands, human lives, and their properties. Pakistan was ranked 5th in those countries in which the highest number of people have affected by floods. Extreme flooding events are considered a reason for forced migration that Extreme flooding events are considered a reason for forced migration. Climaterelated forced displacement can increase various factors, for example, it can create social, hygiene, sanitation, and health issues for both the host and migrant, increase pressure on infrastructure and services, weaken the economic growth of the host communities(IOM, 2009).

Pakistan's central government, with the support of the local governments, must develop flood risk GIS maps and mitigation strategies for each district, taking into account the rainfall intensity, the geology, and the land surface factors. These GIS maps and mitigation strategies can be used as a flood awareness and flood decisionmaking tool. This early warning tool can save the economy, human health and infrastructure of the country, millions of people, and their crops.

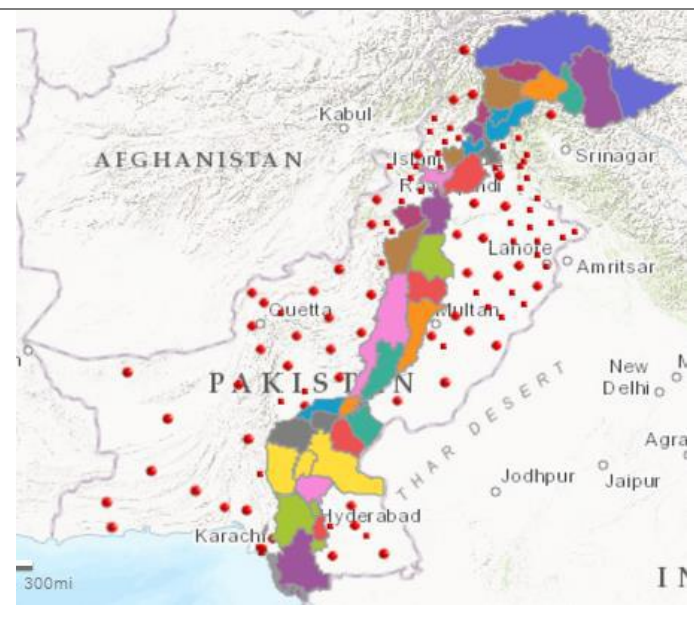

The districts are selected around the Indus river that might affect the selected areas' crops, people and the infrastructure

\section{Fig. 5. Indus River in Pakistan and Districts Expected to Face Flood Risk.}

Source: GIS Map Project, created by Shahzad Ismail

In Pakistan, a few public organizational units have completed some GIS projects to support the disaster management process and to help the NDMA like the NDMA Maps, 2016, the PDMA like PDMA Map, 2016. However, there is no detailed information available regarding GIS data in Pakistan. For instance, the maps are not fully functional, and data sources are not available, who is the owner of the GIS data that was prepared for these projects? There are many reasons the GIS technology is not being appropriately used in Pakistan. First, the software is super expensive; second, the software does not provide national or local level general spatial data; and third, there is a substantial shortage of GIS professionals in Pakistan.

\section{The policies of State Institutions}

The current environmental policy of Pakistan called the NEP was approved in 2005. The policy aimed to manage natural resources and promote economic growth(The National Assembly of Pakistan, 1997). The NEP involves all the main sectors of the environment in its 
strategy to progress the quality of life of the inhabitants. Some measures are taken to preserve the ozone layer by establishing the National Clean Development Mechanism (CDM) authority and promoting the use of environmentally friendly products. Many strategies are discussed in the NEP, but the financial means, financial provisions, and mechanisms of actions to implement these policies are not described in the policy. The policies that were prepared to protect Pakistan's human health, natural resources, and environment, are unrealistic and are not fully implemented so far at the local levels, because all the power remains under the control of the national government and they implement these policies without a financial mechanism at the top level.

According to the NEP, 2005, all the core environmental change policies will be executed at the national level by the MoE-Pakistan and the Pakistan Environmental Protection Agency (Pak-EPA). Although the Pakistan Environmental Protection Act 1997 gives all environment management authorities to provincial governments. Provincial governments must be in power in terms of implementing the policies. There has been very little coordination and association regarding the execution and progress of action plans between the central government agencies and the local government departments (International Monetary Fund, 2010). The policies need to be revised and included the proper role of the local governments with robust financial frameworks for the alleviation of the severe effects of climate degradation and for reducing the space between the federal administration and the local governments.

\section{The Need for Local Government Involvement}

It is necessary that climate change and climaterelated disasters be dealt with at all levels but especially at the local levels. The NDMA was created in 2005 to help as a focal point for disaster management, emergency response, and response management in Pakistan. Then four PDMA was established in each of the four provinces of Pakistan to handle future disasters at the provincial levels. Unfortunately, in Pakistan, all the efforts of disaster management, environmental protection, and conservation of natural resources are being made at the top level so far. Since the NDMA and the PDMA's inception along with the national environmental protection institutions such as Pak-EPA and Ministry of Environment (MoE) have not been successful in implementing the NEP at the district, tehsil, union council, and community levels. As a whole, they have not strengthened their local institutions.
In Pakistan, local governments were created at three levels in 2001 through the announcement of the Local Government Ordinance 2001.

District | City District

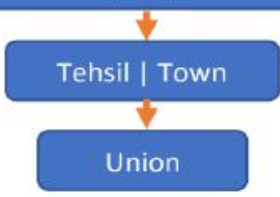

Fig. 6. Hierarchy of three levels of Local Governments.

Source: (Yazdani, 2003)

The district and city district levels are considered the highest level in the local governments in Pakistan, whereas Union, tehsil, and city town levels are considered the lowest level.

Climate change is likely to damage the environmental systems (watersheds, forests), social systems (health care and education centers), and infrastructure, including roads, power supplies, bridges, water, and sewage systems. Generally, these vulnerable and affected assets and infrastructures remain under the control of local governments. They are responsible for handling and delivering a range of quality services to their communities and have the experience to cope with the environmental variation at the local levels. Thus, local level administrations are the main element to achieve real results and solutions regarding environmental and natural resource protection because of three main reasons. First local authorities adopt their specific strategies, for instance, solid waste management rules and land administration regulations. Second, local government officials and employees can join neighborhood groups and organizations and can take affirmative actions to protect the environment and natural resources through lobbying practices. The ideas of other professional people and organizations can be added to the local decision-making processes through lobbying practices. The third reason is that cities have the depth of experience in the field of energy and waste management, public transport, and water supply and management(Linstroth \& Bell, 2007).

As a whole, the disaster management and environmental protection institutions of the Pakistan government are using a top-down approach for disaster management and environmental conservation. That kind of approach does not work effectively. Due to the lack of connection and integrated and harmonious operation with the local governments, the NEP and NCCP police have not been successful in terms of reducing the impacts of climate change. The policies of the NEP, the NCCP, and the NDMA do not have accountability, local planning, or 
financial frameworks. These kinds of aspects and angles in the policies where all the power remains under one agency cannot protect the economy, natural resources of the country, and the people from natural disasters.

\section{CONCLUSION}

Pakistan has suffered most from the impacts of environmental change, which has posed threats to agriculture and food security, water security, and public health because of the weak institution system, unrealistic environmental policies, lack of environmental awareness among officers, and environmentally unsustainable practices. Effective, efficient, and realistic policies with financial accountability framework need to be prepared on an urgent basis for environmental protection and disaster management. The degradation of water resources, healthcare, and climate-related disasters have been happening every year due to climate change that is exacerbating the vulnerability of the country. There is a substantial nexus between air pollution and global warming and public health and disease mortality. Therefore, necessary preventive measures are required at a national level to reduced air pollution, which will bring public health benefits.

NCCP and NEP have a big gap between environmental change adaptation and actions between different levels of actions due to the lack of coordination among the local governments. It can be practical and realistic if the duties and tasks of local departments are defined clearly, and if the actions and financial, accountability, evaluation frameworks are constant. Additionally, climate change planning and judgments regarding environmental conservation should be realistic and take based on the facts through more muscular institutional coordination. Effective climate change adaptation measures require such leadership who supports decisions made at all local levels. The top-down approach of environmental change policy implementation does not work. The local government-based climate change programs' planning and implementation with effective financial management and accountability framework can better cope with the challenges of environmental degradation.

\section{CONCLUSION AND RECOMMENDATIONS}

Nowadays, environmental change has become an urgent issue for Pakistan because more severe climaterelated disasters will damage its national resources, human health, food security, infrastructure, and human lives. In the light of uncertainty concerning future multispectral consequences of environmental change in Pakistan that have been discussed in the discussion section, multi adaptation policies and multi mitigation action plans should be taken to address environmental change.

The disaster management and environmental protection agencies of Pakistan will have to consider more to the climate change adaptation actions. First, the policymakers will have to find the obstacles to adaptation and introduce reasonable and realistic environmental change policy measures that are real and applicable to Pakistan's environmental conditions.

The lack of awareness and closer collaboration has been a significant obstacle to environmental change adaptation. The environmental conservation awareness has now become essential for the citizens and the local officials of Pakistan to accomplish sustainable development and to protect the natural resources of Pakistan. The Pakistan government should establish a national adaptation council of action that would open for all the local governments, which would arrange a platform for closer collaboration, discussion, exchange of information and exchange of ideas on the environmental change adaptation policies and plans for the building environment. This platform would also provide a system for public involvement on the environmental change adaptation needs and plans.

The top-down approach of environmental change policy implementation does not work. The local government-based climate change program planning and implementation with effective financial management and accountability framework can cope better with the challenges of environmental degradation. The government should develop a tool for environmental assessment and awareness and capacity building of the officials and folks. Local governments and climate literate local officers can perform decisive front-line action to tackle environmental problems and natural resources management.

NCCP and NEP have a big gap between its environmental change adaptation and actions due to the lack of coordination among the local governments. The climate-related disasters and the government's climate change projects are managed and handled only at the national and rarely at the provincial levels. The top-down approaches are being used to control environmental change and natural disasters in Pakistan. This kind of approach cannot obtain the best results. The natural disaster management projects and climate change projects must be managed and handled at the local levels for obtaining the best results on time. The NDMA, the PDMA and the MoE in the NEP should clearly state the duties and 
responsibilities of the local governments and enhance the participation of the local governments with more robust institutional coordination in management, and in the protection of the national resources and human health with realistic financial and accountability framework.

Many climate change adaptation policies of the national government have been unsuccessful in achieving the desired results because the policies do not comprise of negative and positive elements of environmental change for the vulnerable sectors that have affected and are affecting due to environmental degradation. For instance, the water sector and the agriculture sector in Pakistan are the most vulnerable sectors to environmental change that are stated in the NEP. Still, the NCCP does not define the harmful effects of environmental change on those sectors and does not state how environmental degradation will affect all aspects of water and agriculture. Such national environmental change policies to protect and manage the natural resources of Pakistan need to be rectified and rationalized.

The disaster management policies of the NDMA mostly focus on achieving short-term humanitarian relief goals and do not recognize climate change perspective. Particularly the disaster management policy of the NDMA is silent about the environmental change adaptation measures, although there is a substantial relation among disaster management and environmental adaptation. The NDMA and the MoE should include, recognize, and strengthen the coordinated method and incorporation of environmental change adaptation in its strategies and projects. They should establish a combined approach to combat environmental change and its risks by considering short to medium-term approach for disaster risk reduction, and short-term approach for disaster response and medium to long term approach for environmental change adaptation.

The central government should prepare practical polices to build household and commercial waste recycling centers for the local governments to collect and dispose of household and commercial waste. The local governments should be forced to turn to recycle waste properly as well as the local authorities need to take action for air pollution monitoring. The national government needs to set air quality and emissions standards to curb emissions on vehicles and power plants, on the use of biomass fuels and coal.

The bright and robust financial framework with the accountability model for environmental change adaptation projects should be established.

\section{REFERENCES}

[1] Ainuddin, S., Aldrich, D. P., Routray, J. K., Ainuddin, S., \& Achkazai, A. (2013). The need for local involvement: Decentralization of disaster management institutions in Baluchistan, Pakistan. International Journal of Disaster Risk Reduction, 6 , 50-58. https://doi.org/10.1016/j.ijdrr.2013.04.001

[2] Awais, P., \& Zareen, S. (2016). Awareness of Climate Change Impacts and Adaptation at Local Level in Punjab, Pakistan. Retrieved October 28, 2016, from https://www.researchgate.net/publication/307861821_Aware ness_of_Climate_Change_Impacts_and_Adaptation_at_Loc al_Level_in_Punjab_Pakistan

[3] Bulkeley, H. (2010). Cities and the Governing of Climate Change. Annual Review of Environment and Resources, 35(1), 229-253. https://doi.org/10.1146/annurev-environ072809-101747

[4] Burton, I., Lim, B., Spanger-Siegfried, E., Malone, E. L., \& Huq, S. (2005). Adaptation policy frameworks for climate change: developing strategies, policies, and measures. Cambridge, UK; New York: Cambridge University Press.

[5] Baaghideh, M., \& Mayvaneh, F. (2017). Climate Change and Simulation of Cardiovascular Disease Mortality: A Case Study of Mashhad, Iran. Iranian Journal of Public Health, 46(3), 396-407.

[6] ESRI. (2014). GIS for Climate Change. Retrieved from http://www.esri.com/library/bestpractices/climatechange.pdf

[7] Germanwatch. (2013). Global climate risk index 2013. 2013. Bonn; Berlin: Germanwatch. Retrieved from https://germanwatch.org/en/download/7170.pdf

[8] Government of Pakistan. (2013). Framework for Implementation of Climate Change Policy 2014-2030. Retrieved November 25, 2016, from

http://www.pk.undp.org/content/dam/pakistan/docs/Environ ment $\% 20 \& \% 20$ Climate $\% 20$ Change/Framework $\% 20$ for $\% 20$ Implementation $\% 20 \mathrm{of} \% 20 \mathrm{CC} \% 20$ Policy.pdf

[9] Howe, C. (2009). The role of education as a tool for environmental conservation and sustainable development. Imperial College London. Retrieved from http://www.iccs.org.uk/wp-content/thesis/phdhowe,caroline09.pdf

[10] International Federation of Red Cross and Red Crescent Societies. (2015). World disasters report 2015: focus on local actors, the key to humanitarian effectiveness. Retrieved from https://ifrc-media.org/interactive/wpcontent/uploads/2015/09/1293600-World-Disasters-Report2015_en.pdf

[11] International Organization for Migration (IOM). (2009). Migration, environment and climate change: Assessing the Evidence. Internat. Organization for Migration.

[12] International Monetary Fund. (2010). Pakistan: Poverty Reduction Strategy Paper. International Monetary Fund.

[13] IPCC - Introduction: Adaptation and Adaptive Capacity. (2016). IPCC - Intergovernmental Panel on Climate Change. Retrieved July 28, 2016, from http://www.ipcc.ch/ipccreports/tar/wg2/index.php?idp=643 
[14] IPCC-WGII (2007). Climate Change 2007 - Impacts, Adaptation and Vulnerability: Working Group II Contribution to the Fourth Assessment Report of the IPCC. Cambridge University Press.

[15] Iqbal, M., Ahmad, M., Khan, M. A., Samad, G., \& Gill, M. A. (2014). Review of Environmental Policy and Institutions (Review of Environmental Policy and Institutions). 06: International Development Research Centre (IDRC-CRDI). Retrieved from http://pide.org.pk/pdf/Climate_Change_4.pdf

[16] Janjua, S. (2011). Opportunities for Climate Change Adaptation in Developing Countries - A Case of Local Governments in Pakistan (Research Base). RMIT University, Melbourne, Australia. Retrieved from https://researchbank.rmit.edu.au/eserv/rmit:160885/Janjua.p df

[17] Jensen, A., Ørsted Nielsen, H., Lilleøre Nielsen, M., \& DCE - Nationalt Center for Miljø og Energi. (2016). Climate adaption in local governance: institutional barriers in Danish municipalities. DCE - Danish Centre for Environment and Energy.

[18] Khan, M. A., Khan, J. A., Ali, Z., Ahmad, I., \& Ahmad, M. N. (2016). The challenge of climate change and policy response in Pakistan. Environmental Earth Sciences, 75(5). https://doi.org/10.1007/s12665-015-5127-7

[19] Linstroth, T., \& Bell, R. (2007). Local Action: The New Paradigm in Climate Change Policy. UPNE.

[20] Lorenzoni, I., \& Pidgeon, N. F. (2006). Public Views on Climate Change: European and USA Perspectives. Climatic Change, 77(1-2), 73-95. https://doi.org/10.1007/s10584006-9072-z

[21] Mayo, S. M., Ahmad, I., Mirza, A. I., Rahman, A., \& Sharif, M. B. (2013). Role of Local Government System in Disaster Risk Reduction: A Case Study of Punjab Province in Pakistan. Virus, 4035. Retrieved from https://www.researchgate.net/profile/Ali_Mirza4/publication /283497057_role_of_local_government_systemin_disaster_r isk_reductiona_case_study_of_punjab_province_in_pakistan /links/563b215008ae337ef298664b.pdf

[22] M.Betsill, M., \& Bulkeley, H. (2006). Cities and the Multilevel Governance of Global Climate Change, Global Governance; Apr-Jun 2006, 141-159.

[23] Ministry of Climate Change. (2016). Multilateral Environmental Agreements (MEAs). Retrieved October 28, 2016,

from http://202.83.164.29/moclc/frmDetails.aspx?opt=misclinks\& $\mathrm{id}=7$

[24] Morrill, A. (2016). Addressing Climate Change at the Municipal Level | Cornell Climate Change. Retrieved November 21, 2016, from http://climatechange.cornell.edu/addressing-climate-changeat-the-municipal-level/

[25] National Climate Change Adaptation Research Facility. (2012). Challenges of adaptation for local governments. NCCARF Australia. $\quad$ Retrieved from https://www.nccarf.edu.au/sites/default/files/attached_files_p ublications/government_070313_a4.pdf
[26] National Research Council, Division on Earth and Life Studies, Board on Atmospheric Sciences and Climate, \& America's Climate Choices: Panel on Adapting to the Impacts of Climate Change. (2011). Adapting to the Impacts of Climate Change. National Academies Press.

[27] NDMA Maps. (2016). NDMA Maps Pakistan. Retrieved December 11, 2016, from http://203.124.39.68/webmaps1/suparco.php

[28] Neuhoff, K. (2015). International Support for Domestic Climate Policies in Developing Countries. Routledge.

[29] OECD. (2006). Adaptation to Climate Change: Key Terms (p. 11). Retrieved from http://www.oecd.org/env/cc/36736773.pdf

[30] Pakistan - On-Farm and Command Water Management and Irrigation Systems Rehabilitation Projects - Independent Evaluation Group (IEG) - The World Bank Group. (2016). Retrieved July 25, 2016, from http://lnweb90.worldbank.org/oed/oeddoclib.nsf/DocUNID ViewForJavaSearch/07A8B67C8A94D0EE852567F5005D3 A1E

[31] PDMA Map. (2016). PDMA Map. Retrieved December 11, 2016, from https://www.pdma.gov.pk/

[32] Rasul, G., \& Ahmad, B. (2012). Climate Change in Pakistan. Pakistan Meteorological Department. Retrieved from https://www.researchgate.net/profile/Maida_Zahid/publicati on/270589207_Climate_Change_in_Pakistan_Focused_on_ Sindh_Province/links/54affb150cf2431d3531cb3f.pdf

[33] San Diego Forward. (2014). Regional Planning Committee Agenda. Retrieved from http://www.sdforward.com/sites/sandag/files/meetingid_352 2_16898\%5Bsmallpdf.com\%5D.pdf

[34] Sansom, G., \& McKinlay, P. (2013). New Century Local Government: Commonwealth Perspectives. Commonwealth Secretariat.

[35] Shahid, Z. (2015). Awareness for Better Adaptation Strategy Development for Climate Change Impacts in Pakistan. Pakistan Journal of Science, 67(4), 419-421.

[36] Shahid, Zareen. (2012). Climate change awareness and adaptation by local planning in Punjab, Pakistan. Retrieved from

http://researchdirect.westernsydney.edu.au/islandora/object/u ws: 17611

[37] Shahid, Zareen, \& Piracha, A. (2016). Awareness of Climate Change Impacts and Adaptation at Local Level in Punjab,

Pakistan. Retrieved from https://www.researchgate.net/profile/Awais_Piracha/publicat ion/307861821_Awareness_of_Climate_Change_Impacts_a nd_Adaptation_at_Local_Level_in_Punjab_Pakistan/links/5 7cf909508ae582e06939395.pdf

[38] Simeone, C. (2006). The Necessity and Possibilities of Constitutional Environmental Rights. Master of Environmental Studies Capstone Projects, 7.

[39] Srivastava, R., \& G, A. (2016). Developing Environmental Awareness Through Open and Distance Learning System. Retrieved from https://www.researchgate.net/publication/304202676_develo 
ping_environmental_awareness_through_open_and_distance _learning_system

[40] The British Council. (2013). Environmental Performance Report, Pakistan. Retrieved October 28, 2016, from https://www.britishcouncil.pk/sites/default/files/environment _performance_report_the_british_council_pakistan.pdf

[41] The Center for Clean Air Policy (CCAP). (2013). Adaptation - Mitigation Synergies. Retrieved October 31, 2016, from http://ccap.org/assets/5a_Udvardy_AdaptationMitigation_Nov-15-2013.pdf

[42] The National Assembly of Pakistan. Pakistan Environmental Protection Act 1997 (1997). Retrieved from https://www.elaw.org/system/files/Law-PEPA-1997.pdf

[43] The U.S. Department of State publishes eJournal USA. (2011). Climate Action Goes Local. Retrieved November 21, 2016, from http://photos.state.gov/libraries/amgov/30145/publicationsenglish/Climate_Action\%20_Goes\%20_Local.pdf

[44] The World Bank. (2010). Cities and Climate Change: An Urgent Agenda. Retrieved from http://siteresources.worldbank.org/INTUWM/Resources/340 232-1205330656272/CitiesandClimateChange.pdf

[45] The World Bank Group. (2011). Guide to Climate Change Adaptation in Cities. Retrieved from http://siteresources.worldbank.org/INTURBANDEVELOP MENT/Resources/336387-

1318995974398/GuideClimChangeAdaptCities.pdf

[46] UN HABITAT, \& ICLEI. (2004). Sustainable Urban Energy Planning. UNON. Retrieved from http://archive.iclei.org/fileadmin/user_upload/documents/Afr ica/Programs/Energy_and_Climate_Change/Sustainable_En ergy_Handbook_Low_Res.pdf

[47] UN OCHA. (2011). Historical Natural Disaster Events. Retrieved July 29, 2016, from http://reliefweb.int/sites/reliefweb.int/files/resources/FL2010-000141-PAK_110716_graph.pdf

[48] UNDP, UNEP, \& UNCDF. (2010). Local Governance and Climate Change. Retrieved July 25, 2016, from https://www.unpei.org/sites/default/files/publications/Local GovernanceAndClimateChangeDiscussionNote.pdf

[49] UNEP. (2000). Developing strategies for climate change: The UNEP country studies on climate change impacts and adaptations assessment. Report/CICERO-Senter for Klimaforskning Http://Urn. Nb. No/URN: NBN: No-3645. Retrieved from https://www.duo.uio.no/handle/10852/32753

[50] UNEP Climate Change Mitigation. (2016). Climate Change Mitigation. Retrieved July 28, 2016, from http://www.unep.org/climatechange/mitigation/Home/tabid/ 104335/Default.aspx

[51] UNESCO. (1992). Intergovernmental Conference on Environmental Education. Cowley Publications. Retrieved from http://www.gdrc.org/uem/ee/EE-Tbilisi_1977.pdf

[52] UNESCO. (2012a). Education in Pakistan. Retrieved October 21, 2016, from http://en.unesco.org/gemreport/sites/gem-

report/files/education_in_pakistan_a_fact_sheet.pdf
[53] United Nations Development Programme. (2003). A Climate Risk Management Approach to Disaster Reduction and Adaptation to Climate Change. IUCN Regional Biodiversity Programme: Colombo, Sri Lanka. Retrieved from https://portals.iucn.org/library/efiles/documents/2003050.pdf

[54] United Nations Environment Programme (UNEP). (2013). Climate change. Retrieved from http://www.unep.org/gc/gc26/factsheet/pdfs/Climate_change .pdf

[55] United Nations Framework Convention On Climate Change. (1992). United Nations Framework Convention On Climate Change 1992 (pp. 26-30). Retrieved from https://unfccc.int/files/essential_background/background_pu blications_htmlpdf/application/pdf/conveng.pdf

[56] Wei Choo, C. (2008). Organizational disasters: why they happen and how they may be prevented. Management Decision, 46(1), 32-45. https://doi.org/10.1108/00251740810846725

[57] World Resources Institute. (2015). Ranking the World's Most Water-Stressed Countries in 2040 | World Resources Institute. Retrieved November 26, 2016, from http://www.wri.org/blog/2015/08/rankingworld\%E2\%80\%99s-most-water-stressed-countries-2040

[58] Yamin, F., Rahman, A., \& Huq, S. (2005). Vulnerability, adaptation and climate disasters: a conceptual overview. IDS Bulletin, 36(4), 1-14.

[59] Yazdani, F. (2003). Women's representation in local government in Pakistan: impact analysis \& future policy implications. Retrieved from http://www.policy.hu/yazdani/finalresearch.html African Ministerial Conference on, Environment. "Climate Change in Africa - What Is at Stake?", 2015.

[60] The Global Opportunity in It-Based Services: Assessing and Enhancing Country Competitiveness. [in en]. Washington, D.C: World Bank, 2010. 